\title{
Performance and parasite control of different genetic groups of lambs finished in irrigated pasture
}

\author{
[Desempenho e controle parasitário de diferentes grupos genéticos de \\ cordeiros terminados em pastagem irrigada] \\ G.A. Fernandes Júnior ${ }^{1}$, R.N.B. Lôbo ${ }^{2 *}$, L.S. Vieira ${ }^{2}$, M.M. Sousa ${ }^{3}$, \\ A.M.B.O. $L_{o} b o^{2}$, O. Facó ${ }^{2}$ \\ ${ }^{1}$ Universidade Estadual Paulista - Unesp - Jaboticabal, SP \\ ${ }^{2}$ Embrapa Caprinos e Ovinos - Sobral, CE \\ ${ }^{3}$ Universidade Estadual Vale do Acaraú - UVA - Sobral, CE
}

\begin{abstract}
The aim of this study was to compare the following four genetic groups of hair sheep: Santa Inês (SI), Morada Nova (MN), Brazilian Somali (BS), and the F1 1/2Dorper x 1/2Morada Nova crossbreed on traits related to growth and parasitic infection. Thirty-three male lambs of the same age and of simple birth, under the same pre-weaning management conditions were used in the experiment. After weaning the animals were housed in a completely randomized design in paddocks made of Panicum maximum cv. Tanzania. Along the course of the research, the performance of the four groups of sheep was observed to be negatively affected by gastrointestinal parasites, but there was a genotype effect to the average daily weight gain (ADWG), where the SI and F1 genotypes presented higher values. The effects of genotype, time and genotype $\mathrm{x}$ time interaction were significant in weight and corporal score (CS) measurements. The BS lambs had the highest CS values throughout the experiment despite not presenting greater weight gain when compared to the SI and F1 breeds. There were also significant effects of time and genotype $\mathrm{x}$ time interaction for packed cell volume (PCV) and FAMACHA $^{\odot}$ score (FAM) and only the time effect was significant in the total number of eggs per gram (EPG) and total plasma protein (TPP). The MN lambs showed higher PCV values and unlike the other groups, presented a FAMACHA $^{\odot}$ score below 3 and PCV above $23 \%$ even having a higher EPG tendency, especially in the initial phase, indicating a possible higher resilience to infection caused by gastrointestinal parasites.
\end{abstract}

Keywords: hair sheep, weight gain, genotype effect

\section{RESUMO}

O objetivo deste estudo foi comparar quatro grupos genéticos de ovinos: Santa Inês (SI), Somalis Brasileira (SB), Morada Nova (MN) e 1/2 Dorper - 1/2 Morada Nova (F1) quanto às características de crescimento e de infecção parasitária. Trinta e três cordeiros machos, de mesma idade, nascidos de parto simples e submetidos às mesmas condições de manejo pré-desmame foram utilizados no experimento. Após o desmame, os animais foram alojados em piquetes de capim Panicum maximum cv. Tanzânia, em um sistema rotativo de pastejo sob um delineamento inteiramente ao acaso. Os resultados mostraram que, ao longo do experimento, o desempenho ponderal dos quatro grupos genéticos foi negativamente afetado pela infecção por endoparasitas, mas o efeito de genótipo foi significativo para ganho de peso médio diário, e os grupos SI e F1 apresentaram melhores médias. $O$ efeito do genótipo, tempo e interação genótipo x tempo foi significativo para o peso e o escore corporal. Os cordeiros da raça SB apresentaram maiores escores corporais ao longo do experimento, apesar do menor ganho de peso quando comparados aos dos grupos SI e F1. Houve efeito significativo do tempo e da interação genótipo x tempo para o hematócrito e para o grau FAMACHA ${ }^{\odot}$. Somente efeito do tempo foi verificado para as características OPG e proteína plasmática total. Os cordeiros da raça Morada Nova, ao contrário dos demais grupos, mantiveram o grau FAMACHA ${ }^{\odot}$ inferior a 3 e hematócrito inferior a $23 \%$, mesmo com tendência de maior OPG, principalmente na fase inicial, indicando uma possível maior capacidade de adaptação à infecção por endoparasitas.

Palavras-chave: ovinos deslanados, ganho de peso, efeito do genótipo

Recebido em 9 de maio de 2014

Aceito em 27 de março de 2015

* Autor para correspondência (corresponding author)

E-mail: raimundo.lobo@embrapa.br 


\section{INTRODUCTION}

The production systems based on irrigated pastures allows for both a significant increase in stocking rate and animal performances (Mahieu et al., 2008) since it enables high yields of forage throughout the year (Ribeiro et al., 2009). The finishing of lambs in these systems with supplementation may contribute to attaining younger animals at slaughter and offering consumers a better quality product (Menezes et al., 2008). The main obstacle for sheep production on irrigated pastures is helminth infections (Cruz et al., 2010), which is responsible for great losses in the system productivity. This can be clearly seen when the economic value of the trait linked to resistance to gastrointestinal helminths in sheep is analyzed (Gicheha and Bett, 2010).

Several studies have been conducted, mainly in tropical regions, with this approach due to huge economic losses caused by parasite infection in small ruminants. Some studies aim to evaluate the efficacy of anthelmintic drugs and risk of parasite resistance (Taylor et al., 2009), while others look for alternative substances and methods to control nematode parasites (AlonsoDíaz et al., 2010; Iqbal et al., 2010). Nowadays, more importance is given to the studies of genetic factors that influence the immune response of animals with the objective of identifying genotypes that have a greater genetic resistance to gastrointestinal nematodes (McManus et al., 2009).

Bishop (2012) recommends a selection based on phenotypic measurements such as performance under conditions of nematode challenge, number of eggs per gram and measures of anaemia, such as packed cell volume or FAMACHA ${ }^{\odot}$ score. Since in Northeastern Brazil the base system for the sheep industry is the pasture, either native or cultivated, and the native breeds are the basis for the genetics population of sheep, being the Santa Inês, Brazilian Somalis and Morada Nova breeds, and the crossbred Dorper breed among the main genetic groups bred in this region (Fernandes Júnior et al., 2013), the aim of this study was to compare the performance of those genetic groups on traits related to growth and natural infection by endoparasites in a finishing system on an irrigated pasture.

\section{MATERIAL AND METHODS}

The experiment was conducted using the experimental flock of Embrapa Caprinos e Ovinos (Embrapa Goats and Sheep), in the city of Sobral, located in the state of Ceará, Brazil, in a semiarid region, $34^{\circ} 2^{\prime}$ south latitude and $40^{\circ} 21^{\prime}$ west longitude, at an altitude of $83 \mathrm{~m}$. Under the Köppen system, the climate in the region is type BSH'w, i.e., mesothermal with summer and autumn rains. The rainy season occurs from January to June, and the dry season from July to December. The average annual temperature is $30^{\circ} \mathrm{C}$ with an annual rainfall of $800 \mathrm{~mm}$.

Thirty-three contemporary male lambs were used in the experiment, being thirteen from the Santa Inês (SI) breed, seven from the Brazilian Somali (SB) breed, six from the Morada Nova (MN) breed and seven from the $1 / 2$ Dorper - $1 / 2$ Morada Nova (F1) crossbreed. All lambs were of simple birth and received the same pre-weaning management under a semi-intensive system on a native pasture. After weaning, at an average age of $94 \pm 7.5$ days, the lambs were housed in paddocks made of Panicum maximum cv. Tanzania and given water and mineral salt $a d$ libitum. They were supplemented once a day with concentrate (48\% - corn; $35 \%$ - cottonseed meal; $15 \%$ - soybean; $1 \%$ - limestone; $1 \%$ mineral salt) at a rate of $1.5 \%$ body weight. The occupation period in each paddock was five days.

Weight measurements were taken throughout the experiment, thus, weight gain was examined at different stages. The corporal score was analyzed together with parasite control traits, starting at 35 days of grazing. The lambs were analyzed weekly regarding their FAMACHA $^{\odot}$ (FAM) score, packed cell volume (PCV), total plasma protein (TPP), total number of eggs per gram of faeces (EPG) and coproculture. To prevent deaths, a de-wormer was required at 63 days of grazing due to a very high level of parasitic infection was observed from the data collected.

Fecal egg counts were determined by using the modified McMaster technique (Gordon and Whitlock, 1939), in which each nematode egg counted represented 100 eggs per gram of feces. Blood samples were collected through jugular vein puncture and placed into vacutainer tubes containing EDTA. The PCV was determined using micro-hematocrit centrifugation and the TPP was estimated using a refractometer. 
In the last week of the experiment the lambs were subjected to morphometric measurements using a measuring tape and a zoo-metric stick. With the animals held still on a flat surface, the following characteristics were measured: withers height (WH) - the highest point measured from the withers to the ground; rump height $(\mathrm{RH})$ measured from the highest point of the hock to the ground; body length (BL) - measured from the cranial tip of the scapula and the distal tip of the buttock; thoracic perimeter (TP) corresponds to the circumference taken around the chest cavity; thoracic depth (TD) - distance between the vertebral column starting from the first thoracic vertebra to the sternum; chest width (CW) - distance between the two scapulas; rump length (RL) - distance between the tip of the ileum and the tip of the buttock; and rump width $(\mathrm{RW})$ - distance between the outer tip of the ileum and the left outer edge of the right ileum.

Statistical analyses were performed using the Statistical Analysis System (SAS Institute Inc, 1996) using a completely randomized design with the four genotypes. The traits Wt, FAM, $\mathrm{CS}, \mathrm{PCV}$, TPP, and EPG were evaluated through a multivariate analysis using the GLM REPEATED Statement with polynomial option. Logarithmic transformation was used for EPG $(\log 10 \mathrm{EPG}+5)$ and FAM $(\log 10$ FAM) to meet the assumptions of a multivariate analysis of variance.

\section{RESULTS}

The genotype explained $54.2 \%, 57.5 \%$, and $39.0 \%$ of the total variation in the initial and final weight and average daily weight gain (ADWG) during the trial, respectively. There was no statistical difference between the initial weight of the Santa Inês and Brazilian Somali lambs. The latter also did not differ by the F1 genotype. The Morada Nova lambs had a lower initial weight when compared to the other groups. The Santa Inês lambs had a higher final weight when compared to the other groups, however, its ADWG was similar to the F1 genotype. The genetic groups F1 and Brazilian Somali were similar and superior to Morada Nova in the final weight. The ADWG of Brazilian Somali and Morada Nova were similar and lower than those in the F1 and Santa Inês breeds. There were significant genotype effects in all morphometric traits and a high positive association was observed between them regarding weight and weight gain (Table 1).

The ADWG is presented in Table 2 broken into two periods of the experiment, before worming (initial period) and after worming (final period). The ADWG of all genotypes was higher after worming when compared to before worming. Similarly, the ADWG of the SI and F1 lambs had the highest values in the initial and final period (Table 2) when considering the entire experimental period (Table 1).

Table 1. Genotype effect on weight and average daily weight gain and morphometric measurements in different genetic groups of lambs on intensive rotational grazing system

\begin{tabular}{|c|c|c|c|c|c|c|}
\hline \multirow{2}{*}{ Variables } & \multicolumn{4}{|c|}{ Genotypes } & \multirow{2}{*}{ r.m.s.e. } & \multirow{2}{*}{ P-value } \\
\hline & SI & $\mathrm{BS}$ & $\mathrm{MN}$ & F1 & & \\
\hline \multicolumn{7}{|l|}{ Body weight (kg) } \\
\hline Initial & $20.3 \mathrm{a}$ & $18.0 \mathrm{ab}$ & $12.2 \mathrm{c}$ & $16.7 b$ & 2.8 & $<0.0001$ \\
\hline Final & $26.4 \mathrm{a}$ & $20.6 b$ & $15.7 \mathrm{c}$ & $22.5 b$ & 3.6 & $<0.0001$ \\
\hline ADWG (g/Day) & $67.4 \mathrm{a}$ & $28.7 b$ & $39.0 \mathrm{~b}$ & $63.6 \mathrm{a}$ & 21.7 & 0.0022 \\
\hline \multicolumn{7}{|l|}{ Morphometry (cm) } \\
\hline Withers height & $57.0 \mathrm{a}$ & $48.8 b$ & $47.3 b$ & $49.6 b$ & 3.0 & $<0.0001$ \\
\hline Rump height & $58.9 \mathrm{a}$ & $49.8 b$ & $47.9 \mathrm{~b}$ & $49.8 b$ & 2.8 & $<0.0001$ \\
\hline Thoracic perimeter & $67.9 \mathrm{a}$ & $64.6 a b$ & $56.9 \mathrm{c}$ & $64.0 \mathrm{~b}$ & 4.0 & $<0.0001$ \\
\hline Thoracic depth & $21.1 \mathrm{a}$ & $19.4 \mathrm{~b}$ & $17.2 \mathrm{c}$ & $19.3 b$ & 1.6 & 0.0004 \\
\hline Chest width & $12.5 \mathrm{a}$ & $10.8 b$ & $9.4 \mathrm{c}$ & $12.1 \mathrm{a}$ & 1.2 & $<0.0001$ \\
\hline Rump width & $9.38 \mathrm{a}$ & $8.04 \mathrm{~b}$ & $6.62 c$ & $8.56 b$ & 0.8 & $<0.0001$ \\
\hline Body length & $57.5 \mathrm{a}$ & $45.6 \mathrm{c}$ & $47.6 \mathrm{c}$ & $52.8 b$ & 3.1 & $<0.0001$ \\
\hline Rump length & $14.9 \mathrm{a}$ & $13.6 \mathrm{~b}$ & $11.9 \mathrm{c}$ & $13.8 \mathrm{~b}$ & 1.2 & $<0.0001$ \\
\hline
\end{tabular}

Least-square means in row followed by same letter do not differ by $\mathrm{t}$ test $(\mathrm{P}>0.05)$;

ADWG = average daily weight gain; SI = Santa Inês; $\mathrm{BS}=$ Brazilian Somali; $\mathrm{MN}=$ Morada Nova; F1 = 1/2 Dorper $\mathrm{x}$ $1 / 2$ Morada Nova; r.m.s.e. $=$ root mean square error; 
Performance and parasite...

Table 2. Genotype effect on average daily weight gain before worming and after worming in different genetic groups of lambs on intensive rotational grazing system

\begin{tabular}{lcccccc} 
& \multicolumn{9}{c}{ Genotypes } & \multirow{2}{*}{ r.m.s.e } & \multirow{2}{*}{ P-value } \\
\cline { 2 - 5 } & SI & BS & MN & F1 & & \\
\hline Before worming & $46.5 \mathrm{ab}$ & $18.2 \mathrm{c}$ & $24.5 \mathrm{bc}$ & $56.0 \mathrm{a}$ & 28.0 & 0.0467 \\
After worming & $112.0 \mathrm{a}$ & $51.2 \mathrm{~b}$ & $70.1 \mathrm{~b}$ & $80.0 \mathrm{ab}$ & 52.3 & 0.0977 \\
\hline
\end{tabular}

Least-square means in row followed by same letter do not differ by t test $(\mathrm{P}>0.05)$;

SI = Santa Inês; BS = Brazilian Somali; MN = Morada Nova; F1 = 1/2 Dorper x 1/2 Morada Nova; r.m.s.e. $=$ root mean square error;

The coproculture results showed the presence of gender Haemonchus sp. and Trichostrongylus sp. in the samples analyzed (Fig. 1). The presence of Strongyloides sp. was observed in the samples collected before day 63. The trajectories of $\mathrm{Wt}$, CS, EPG, FAM, PCV and TPP are presented in Fig. 2 (2A, 2B, 2C, 2D, 2E and $2 \mathrm{~F}$, respectively).
The effects of genotype, time and genotype $\mathrm{x}$ time interaction were significant in $\mathrm{Wt}$ and CS. There were also significant effects of time and genotype $\mathrm{x}$ time interaction in PCV and FAM. Only time effect was significant in EPG and TPP.

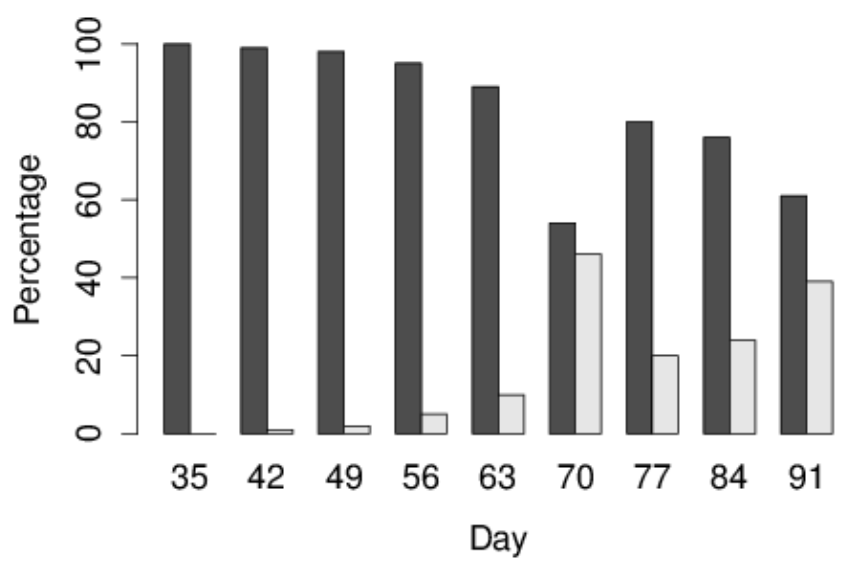

Figure 1. Coproculture analysis on each day of sample collection. Dark bars correspond to Haemonchus sp. and light bars correspond to Trichostrongylus sp.

The Brazilian Somali lambs had the highest CS values during the experiment. Its values were always significantly higher than those observed in Morada Nova, but only superior to F1 and Santa Inês in the $1^{\text {st }}, 2^{\text {nd }}, 6^{\text {th }}, 7^{\text {th }}$ and $8^{\text {th }}$ weeks of evaluation. The CS in F1 and Santa Inês were similar over time $(\mathrm{P}>0.05)$. The $\mathrm{CS}$ in Morada Nova was similar to that of Santa Ines and F1 only in the $6^{\text {th }}$ week.

The EPG was similar between the genetic groups along the experiment, except in the $4^{\text {th }}$ week of evaluation, where the Morada Nova lambs presented higher EPG values than the Brazilian Somali lambs $(\mathrm{P}<0.05)$. There were significant differences between the FAM of the genetic groups in the $5^{\text {th }}$ and $8^{\text {th }}$ weeks of evaluation, but unlike other groups, the Morada Nova lambs presented a FAM score below 3 and PCV above $23 \%$ even with a higher EPG tendency, especially in the initial phase.

PCV decreased until the $5^{\text {th }}$ week, when the lambs in all groups gradually restored their initial values after de-worming. Except in the $1^{\text {st }}$ and $8^{\text {th }}$ week, differences were observed between the genotypes in this trait $(\mathrm{P}<0.05)$. The Morada Nova lambs had higher PCV values along the weeks, except in the $9^{\text {th }}$ evaluation, differing from Santa Inês in the $5^{\text {th }}, 6^{\text {th }}$, and $7^{\text {th }}$ week and from F1 in the $5^{\text {th }}$ week. Santa Inês and F1 had distinct averages in the $6^{\text {th }}, 7^{\text {th }}$, and $9^{\text {th }}$ week, with the highest PCV for F1 $(\mathrm{P}<0.05)$. 
2A

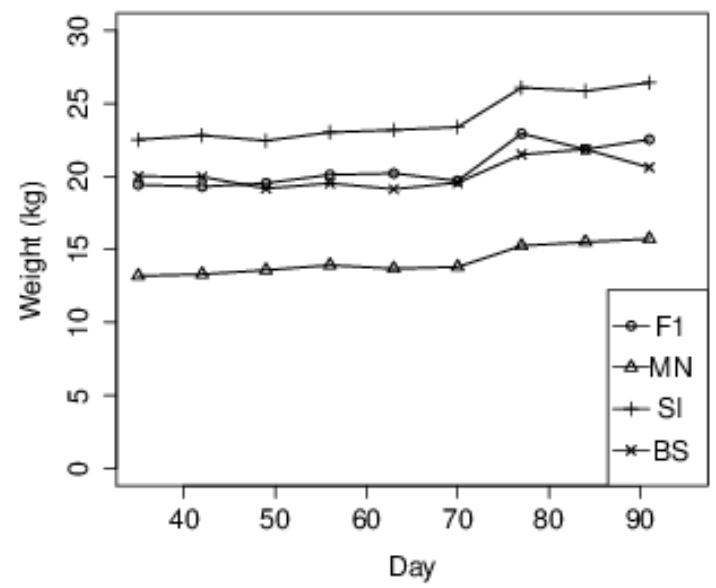

$2 \mathrm{C}$

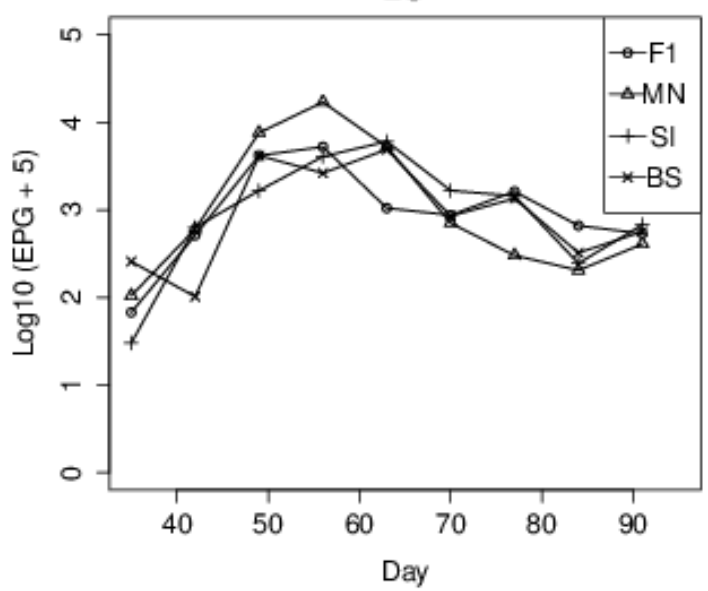

2E

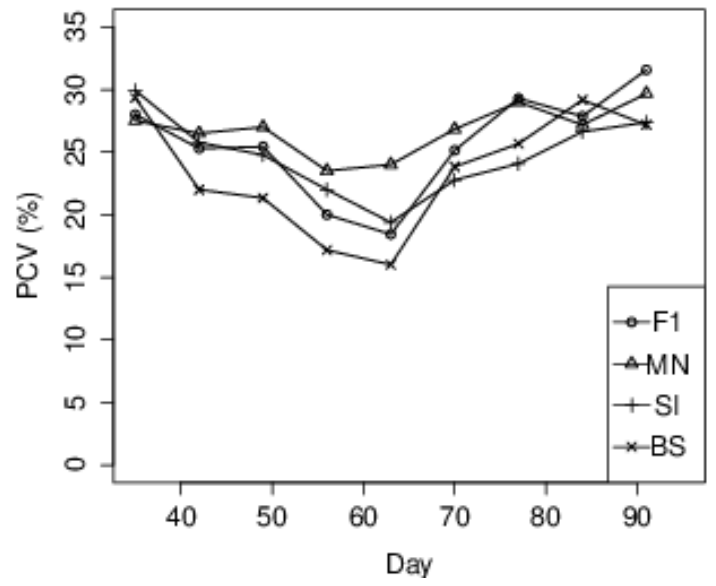

2B

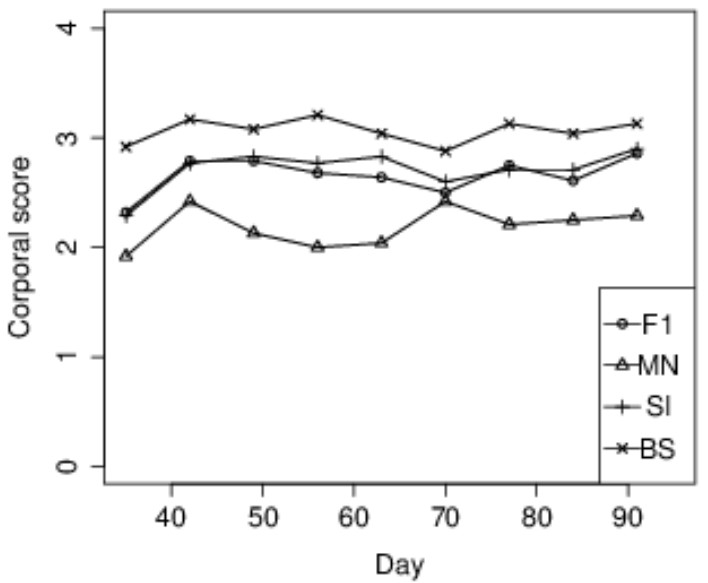

2D

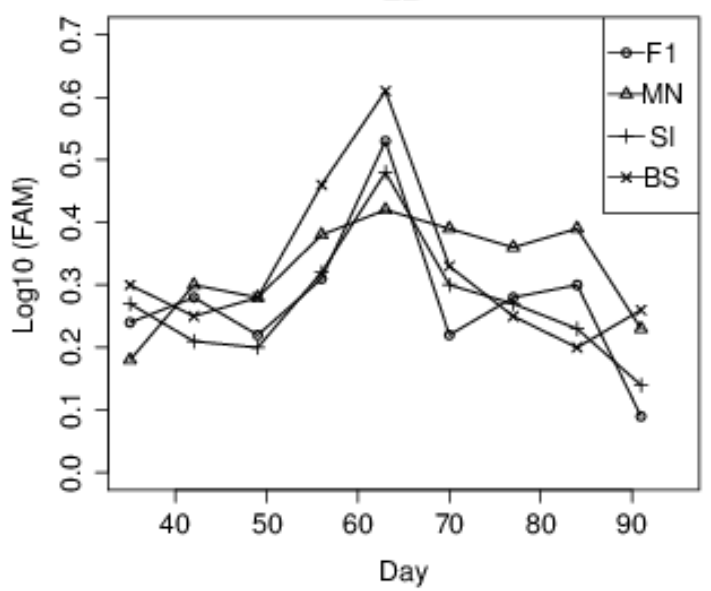

2F

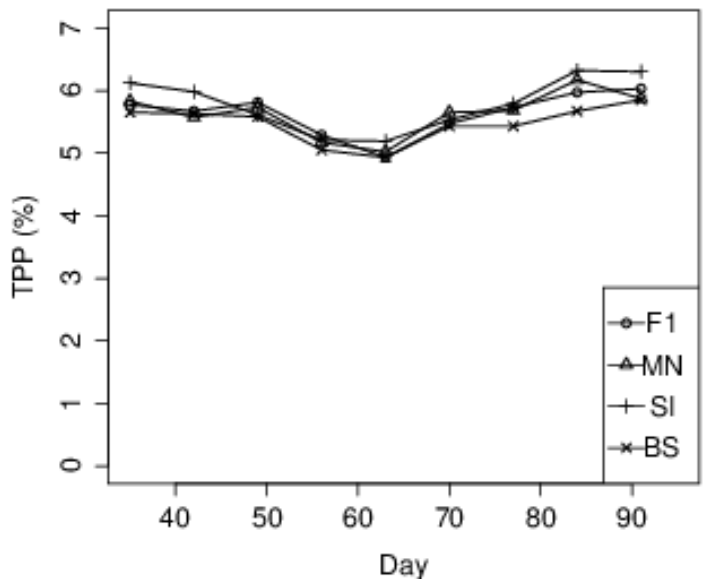

Figure 2. Trajectory of the body weights (Wt; 2A), corporal score (CS; $2 \mathrm{~B})$, egg count per gram of faeces $(\mathrm{EPG} ; 2 \mathrm{C})$, FAMACHA $^{\odot}$ score (FAM; 2D), packed cell volume (PCV; 2E) and total plasma protein (TPP; 2F) of genotypes Santa Inês (SI), Morada Nova (MN), Brazilian Somali (BS) and 1/2 Dorper x 1/2 Morada Nova (F1). 


\section{DISCUSSION}

This study aimed to elicit practical responses from a commercial production system with the lambs finished on an irrigated pasture, where animals are exposed to various challenges such as rain, heat and parasites. In general, genotypes showed satisfactory weight gain considering that there is a known decrease in animal productivity in animals affected by internal parasites (Molento et al., 2004; Costa et al., 2011). In this study, the weight gain of genotypes rose after deworming (Table 2). This can be explained by the fact that during the parasitic challenge, the animals practically do not gain any weight due to the large number of infective larvae on the pasture (Amarante et al., 2004).

Under the environmental and management conditions employed in this study, in comparison to the Brazilian Somali and Morada Nova breeds, the Santa Inês and 1/2 Dorper x 1/2 Morada Nova crossbreed were superior in weight gain when considering the entire experimental period. This result corroborates with several studies that demonstrate the differences in the growth potential of these genetic groups. Quesada et al. (2002), for example, reported higher weights in Santa Inês in relation to Morada Nova, with the lambs kept under extensive grazing. Cloete et al. (2000) made reference to the higher weight gains of the Dorper breed under different management conditions and Carneiro et al. (2007) reported this potential in the growth of the Dorper race which availed into various systems of crossbreeding with local breeds.

According to Costa Júnior et al. (2006), there is no one breed superior to another for meat production in any farming system. It is unclear whether the larger or smaller frame size of a breed determines greater productivity. It is possible that a specific type or size may be more adapted to one specific condition of creation. This way, the body measurements in a comparative study of performance of different genotypes can serve as an aid to understanding the productive differences between breeds, enabling assessment of animal body growth. The thoracic perimeter and chest width, for example, are indicative measures of the respiratory and digestive capacity of animals, which influence total food consumption, and thus, influence weight gain.
In this context, Costa Júnior et al. (2006) and Gusmão Filho et al. (2009) observed a high correlation between measurements of height and thoracic perimeter with the body weight in the Santa Inês breed. In this study, differences between genetic groups were observed in relation to the morphometric measurements (Tab. 1) and high correlation coefficients between weight and weight gain in all morphometric measurements analysed were verified, where the values varied from 0.51 to 0.96 . This helps explain the greater ADWG of Santa Inês when compared to the Morada Nova and Brazilian Somali breeds, which have greater heights and lengths. Larger animals tend to have higher weight gain rates. However, the F1 and Santa Inês genotypes had equivalent $\mathrm{ADWG}$, even though they are smaller in height and length. Certainly, this similar growth rate achieved by crossbreeds in Santa Inês depends a lot more on the maximum heterozygosity achieved in this type of crossing (Carneiro et al., 2007).

In this study, the Brazilian Somali had a TP similar to Santa Inês, even while having a lower ADWG. This may be related to the characteristics of this breed in accumulating fat in some parts of the carcass (Silva et al., 1998) since one of the points where this deposition occurs is the region of the sternum, hence increasing the TP measurement. Another area of fat accumulation in Brazilian Somali is in the rump region. This helps explain the higher corporal score (Figure 2B) of the Brazilian Somali breed since that breed did not show greater weight gain when compared to Santa Inês and F1. We suggest caution, therefore, when corporal score is used to measure the weight development of animals in this breed.

The growth curve represented by differences in body weight and corporal score of the lambs showed an ascending trend in all genotypes, despite fluctuations along the weeks. These fluctuations are normal due to environmental variations in the system related to changes in paddocks, parasitic infection, stress arising from the collection of information, etc. However, in the interval from the $6^{\text {th }}$ to the $7^{\text {th }}$ week of evaluation, the ADWG was $461.2 \mathrm{~g} /$ day, 207.1 g/day, $384.6 \mathrm{~g} /$ day and $275.5 \mathrm{~g} /$ day, respectively, in the F1, Morada Nova, Santa Inês and Brazilian Somali lambs, values much higher than the averages for the total period. As shown in Fig. 
2C, 2D and 2E, all groups presented higher EPG and FAM values and lower PCV values during the $5^{\text {th }}$ week of evaluation. At that time the anthelmintic treatment was administered to restore the physiological conditions of the lambs. This may have triggered compensatory weight gain, explaining the greatest growth in the range from the $6^{\text {th }}$ to the $7^{\text {th }}$ week. It is noteworthy that gastrointestinal parasitism is the main limiting factor in the finishing of lambs on irrigated pasture. The levels of environmental contamination remain high, following the high levels of soil moisture and this results in an increased parasite burden affecting the animals.

The lambs were de-wormed in the $5^{\text {th }}$ week only, however, in general, a trend of an increase in EPG in the initial phase and consequent reduction in the final stage can be observed. This may be related to the triggering of immune responses and consequent resistance of animals to parasitism, a factor also reported by Abrão et al. (2010) and reinforced by the work of McManus et al. (2009) and Lôbo et al. (2009). In the latter, according to the authors, the heritability for EPG increased with infection. Thus, some animals or genotypes have a greater capacity to resist parasites than others. This explains the pattern of EPG found in that research. McManus et al. (2009) pointed out that genetic selection against these parasite infections can result in more resistant animals.

Research indicates that the Santa Inês breed is more resistant to endoparasites in comparison with the Suffolk, Ile de France and Poll animal breeds (Amarante et al., 2004; Rocha et al., 2004; Costa et al., 2007). According to McManus et al. (2009) hair breeds (SI and MN) may naturally be more resistant to parasite infections in comparison to breeds with European blood (pure or crossbred). Generally, lower EPG and higher PCV values present under high parasitic challenges are indicative of higher resistance (Costa et al., 2007). On the other hand, in this study, unlike other groups, the Morada Nova lambs presented a FAMACHA ${ }^{\odot}$ score below 3 and packed cell volume above $23 \%$ even though they had a tendency for a higher number of eggs per gram of feces, especially in the initial phase, indicating a trend towards greater resilience in the Morada Nova breed, with better adaptability to infection by worms.
It is worth mentioning the difference among resistance and resilience to infection by worms. In the first case, the immune response avoids or restricts the establishment of the parasite, and in the second case, the animal is infected by the parasite, in either case it manages to maintain some level of production. In the words of Albers et al. (1987) "resistance is the ability to suppress establishment and/or subsequent development of infection, and resilience is the ability to maintain a relatively unrepressed production level when infected".

The decline pattern in PCV in the Morada Nova lambs (Figure 2E) occurred in a smaller proportion than those of other genotypes. In addition, it reached the lowest value in the $4^{\text {th }}$ week of evaluation, i.e., the breed interrupted the downward trend even before de-worming, unlike other genotypes, which maintained the decline pattern until the time they were de-wormed. This strengthens the indication of Morada Nova lambs having greater resilience to infection by gastrointestinal parasites.

The equivalence in PCV values between the F1 and Morada Nova breeds in eight of nine measurements can be explained by the genetic similarity between the two, since half of the genes in F1 came from Morada Nova. This indicates that the higher capacity that the Morada Nova presents in maintaining the PCV under high parasitic challenges can be transmitted to its crossbreeds. Likewise, Amarante et al. (2009) concluded that crossbreeding Santa Inês sheep with any of the breeds evaluated (Dorper, Ile de France, Suffolk, and Texel) can result in production increase and a satisfactory degree of infection resistance, especially against Haemonchus contortus and Trichostrongylus colubriformis, the major nematodes detected in this flock.

In the $2^{\text {nd }}$ week of evaluation, the PCV of the Brazilian Somali lambs dropped from $29.33 \%$ to $22 \%$, reaching $16 \%$ in the fifth week of evaluation, returning to $29 \%$ in the $8^{\text {th }}$ week (Figure 2E). This pattern was different from the Morada Nova from the $2^{\text {nd }}$ to the $6^{\text {th }}$ week, from Santa Inês in the $2^{\text {nd }}$ and $4^{\text {th }}$ weeks and from F1 in the $9^{\text {th }}$ week $(\mathrm{P}<0.05)$. This apparent sensitivity to worm infection in the Brazilian Somali breed can be explained by its origin and development in Brazil. This breed came to Brazil 
more recently than the precursors of Santa Inês and Morada Nova breeds. In the late 1930s, it was first raised in the state of Rio de Janeiro and then later was brought to the Northeast region, where they adapted better to the dry climatic conditions (Lôbo et al., 2012). Therefore, these animals did not experience great challenges related to worm infections in the semiarid Northeastern region of Brazil, having low rainfall just as in its original region, Somalia and Ethiopia.

The TPP showed the same pattern as that PCV over the weeks, with gradual decline until the $5^{\text {th }}$ week and a subsequent rise until reaching the levels of the first week. With an increase in EPG, the FAM increases and PCV and TPP decrease. This has a direct influence on ADWG and CS, being in agreement with Abrão et al. (2010). These authors, working with Santa Inês crossbreed, reported correlations between EPG and FAM of 0.36 , between EPG and PCV of 0.45 , between EPG and CS of -0.31 , between FAM and PCV of -0.45 , between FAM and CS of -0.20 , and between PCV and CS of 0.41. It is noteworthy to mention that in that study, there was a low correlation between EPG and FAM (0.36). Caution is emphasized in the exclusive use of FAM to estimate EPG. Variations of EPG, especially at the beginning and end of the period were not accompanied by the same magnitude of variation of the FAM scale. Additionally, there is some delay between the increase in EPG and the increase in FAM. Furthermore, there were differences in this pattern among the different genotypes.

These results demonstrated that in order to adopt an appropriate management practice to assess gastrointestinal parasitism, more than one criteria should be used. The use of only EPG or FAM may lead to biased assessments. Variations in EPG are not readily observed by variations in the FAM score. Molento et al. (2004), working with crossbred sheep, found that even with EPG counts above 1500 in various animals, no signs of anaemia were observed, which agrees with that study.

\section{CONCLUSION}

The performance of the four groups was negatively affected by parasitic infection. This confirms that worms are a limiting factor for sheep production on irrigated pastures. The FAMACHA $^{\odot}$ method, together with the EPG technique and blood parameters are important tools in parasitic diagnosis and they can serve to identify genotypes that are more resilient or adapted to parasitic infection. In this study, despite the similarity in the parameters related to gastrointestinal parasitism among the genotypes, there is a definite trend towards greater resilience in the Morada Nova breed, having adaptability to infection by gastrointestinal parasites.

\section{ACKNOWLEDGEMENTS}

The authors acknowledge Embrapa for the financial support. The first author thanks "Fundação Cearense de Apoio ao Desenvolvimento Científico e Tecnológico FUNCAP" and "Universidade Federal do Ceará UFC" for the studentship.

\section{REFERENCES}

ABRÃO, D.C.; ABRÃO, S.; VIANA, C.H.C.; VALLE, C.R. Utilização do método famacha no diagnóstico clínico individual de haemoncose em ovinos no sudoeste do Estado de Minas Gerais. Rev. Bras. Parasitol. Vet., v.19, p.70-72, 2010.

ALBERS, G.A.A.; GRAY, G.D.; PIPER, L.R. et al. The genetics of resistance and resilience to Haemonchus contortus infection in young merino sheep. Int. J. Parasitol., v.17, p.1355-1363, 1987.

ALONSO-DÍAZ, M.A.; TORRES-ACOSTA, J.F.J.; SANDOVAL-CASTRO, C.A.; HOSTE, H. Tannins in tropical tree fodders fed to small ruminants: a friendly foe?. Small Rumin. Res., v.89, p.164-173, 2010.

AMARANTE, A.F.T.; BRICARELLO, P.A.; ROCHA, R.A.; GENNARI, S.M. Resistance of Santa Ines, Suffolk and Ile de France sheep to naturally acquired gastrointestinal nematode infections. Vet. Parasitol., v.120, p.91-106, 2004.

AMARANTE, A.F.T.; SUSIN, I.; ROCHA, R.A. et al. Resistance of Santa Ines and crossbred ewes to naturally acquired gastrointestinal nematode infections. Vet. Parasitol., v.165, p.273-280, 2009.

BISHOP, S.C. Possibilities to breed for resistance to nematode parasite infections in small ruminants in tropical production systems. Animal, v.6, p.741-747, 2012.

CARNEIRO, P.L.S.; MALHADO, C.H.M.; SOUZA JÚNIOR, A.A.O. et al. Desenvolvimento ponderal e diversidade fenotípica entre cruzamentos de ovinos Dorper com raças locais. Pesqui. Vet. Bras., v.42, p.991-998, 2007. 
CLOETE, S.W.P.; SNYMAN, M.A.; HERSELMAN, M.J. Productive performance of Dorper sheep. Small Rumin. Res., v.36, p.119-135, 2000.

COSTA, R.L.D.; BUENO, M.S.; VERÍSSIMO, C.J. et al. Performance and nematode infection of ewe lambs on intensive rotational grazing with two different cultivars of Panicum maximum. Trop. Anim. Health Prod., v.39, p.255-263, 2007.

COSTA, V.M.M.; SIMÕES, S.V.D.; RIET-CORREA, F. Controle das parasitoses gastrintestinais em ovinos e caprinos na região semiárida do Nordeste do Brasil. Pesqui. Vet. Bras., v.31, p.65-71, 2011.

COSTA JÚNIOR, G.S.; CAMPELO, J.E.G.; AZEVÊDO, D.M.M.R. et al. Caracterização morfométrica de ovinos da raça Santa Inês criados nas microrregiões de Teresina e Campo Maior, Piauí. Rev. Bras. Zootec., v.35, p.2260-2267, 2006.

CRUZ, D.G.; ROCHA, L.O.; ARRUDA, S.S. et al. Anthelmintic efficacy and management practices in sheep farms from the state of Rio de Janeiro, Brazil. Vet. Parasitol., v.170, p.340-343, 2010.

FERNANDES JÚNIOR, G.A.; LÔBO, R.N.B.; MADRUGA, M.S. et al. Genotype effect on carcass and meat quality of lambs finished in irrigated pastures in the semiarid Northeastern Brazil. Arq. Bras. Med. Vet. Zootec., v.65, p.1208-1216, 2013.

GICHEHA, M.G.; BETT, R.C. Increasing accuracy in estimation of economic values for resistance to gastrointestinal helminths in meat sheep. Trop. Anim. Health Prod., v.42, p.391-396, 2010.

GORDON, H.M.C.L.; WHITLOCK, H.V. A new technique for counting nematode eggs in sheep faeces. J. Council Sci. Ind. Res., v.12, p.50-52, 1939.

GUSMÃO FILHO, J.D.; TEODORO, S.M.; CHAVES, M.A.; OLIVEIRA, S.S. Análise fatorial de medidas morfométricas em ovinos tipo Santa Inês. Archiv. Zootec., v.58, p.289-292, 2009.

IQBAL, Z.; LATEEF, M.; JABBAR, A.; GILANI, A.H. In vivo anthelmintic activity of Azadirachta indica A. Juss seeds against gastrointestinal nematodes of sheep. Vet. Parasitol. v.168, p.342-345, 2010.

LÔBO, R.N.B.; VIEIRA, L.S.; OLIVEIRA, A.A. et al. Genetic parameters for faecal egg count, packedcell volume and body-weight in Santa Inês lambs. Genet. Mol. Biol., 2009.
LÔBO, A.M.B.O.; GUIMARÃES, S.E.F.; PAIVA, S.R. et al. Differentially transcribed genes in skeletal muscle of lambs. Livest. Sci., v.150, p.31-41, 2012.

MAHIEU, M.; ARCHIMEDE, H.; FLEURY, J. et al. Intensive grazing system for small ruminants in the Tropics: The French West Indies experience and perspectives. Small Rumin. Res. v.77, p.195-207, 2008.

McMANUS, C.; LOUVANDINI, H.; PAIVA, S.R. et al. Genetic factors of sheep affecting gastrointestinal parasite infections in the Distrito Federal, Brazil. Vet. Parasitol., v.166, p.308-313, 2009.

MENEZES, L.F.O.; LOUVANDINI, H.; MARTHA JÚNIOR, G.B. et al. Características de carcaça, componentes não-carcaça e composição tecidual e química da $12^{\mathrm{a}}$ costela de cordeiros Santa Inês terminados em pasto com três gramíneas no período seco. Rev. Bras. Zootec., v.37, p.1286-1292, 2008.

MOLENTO, M.B.; TASCA, C.; GALLO, A. Et al. Método Famacha como parâmetro clínico individual de infecção por Haemonchus contortus em pequenos ruminantes. Cienc. Rural, v.34, p.1139-1145, 2004.

QUESADA, M.; McMANUS, C.; COUTO, F.A.A. Efeitos genéticos e fenotípicos sobre características de produção e reprodução de ovinos deslanados no Distrito Federal. Rev. Bras. Zootec., v.31, p.342-349, 2002.

RIBEIRO, E.G.; FONTES, C.A.A.; PALIERAQUI, J.G.B. et al. Influência da irrigação, nas épocas seca e chuvosa, na produção e composição química dos capins napier e mombaça em sistema de lotação intermitente. Rev. Bras. Zootec., v.38, p.1432-1442, 2009.

ROCHA, R.A.; AMARANTE, A.F.T.; BRICARELLO, P.A. Influence of reproduction status on susceptibility of Santa Inês and Ile de France ewes to nematode parasitism. Small Rumin. Res., v.55, p.65-75, 2004.

SILVA, F.L.R.; ARAÚJO, A.M.; FIGUEIREDO, E.A.P. Características de Crescimento e de Reprodução em Ovinos Somalis no Nordeste Brasileiro. Rev. Bras. Zootec., v.27, p.1107-1114, 1998.

TAYLOR, M.A.; LEARMOUNT, J.; LUNN, E. et al. Multiple resistance to anthelmintics in sheep nematodes and comparison of methods used for their detection. Small Rumin. Res., v.86, p.67-70, 2009.

USER'S Guide. Cary, NC: SAS Institute Inc., 1996. 